\title{
Articles
}

\section{One More Way How to Improve the Higher Education Teaching}

\section{Dana Dobrovská}

\begin{abstract}
Much of higher education stresses the elimination of emotions in exchange for cool, analytic detachment. The idealized picture of the impartial student who engages in logically precise reasoning is the traditional norm to which we wish our students to aspire. Students confronted with the average university teaching are often left baffled why anyone would devote his or her life to the study of such limp material. But the traditional lecture format is not always the most effective way of transferring information. That is why we should pay attention to the powerful affective impact that a live lecture can deliver.

There is no doubt students like to attend some teachers' classes more than the other's. Social psychology and sociology researched the topic of charismatic leaders trying to analyse their personal profiles and methods.

In our paper we intend to shed more light on the concept of teacher charisma and to identify qualities charismatic teaching is characterized by.
\end{abstract}

Keywords: teaching; learning; teacher behaviour; charisma; charismatic teaching. 


\title{
K dalším možnostem zkvalitnění výuky na vysoké škole
}

\begin{abstract}
Abstrakt
Značná část vysokoškolské výuky směřuje k potlačení zapojení emocí a upřednostňuje strohý analytický odstup. Ve výuce učitelé většinou usilují o přiblížení se idealizovanému modelu studenta, jehož studijní aktivity probíhají v logicky přesném schématu uvažování. Studenti si tak navykají na tradiční výuku mající podobu takto pojatého učiva. Tradiční formát vysokoškolské přednášky nemusí být nejúčinnějším prostředkem, jak studijní materiál studentům zprostředkovat. Proto by učitelé neměli zanedbávat vliv emocí, jež mohou hrát při vyučování značnou roli.

Není pochyb o tom, že studenti mají v oblibě přednášky některých učitelů více než jiných. Sociální psychologie a sociologie se již v minulosti zabývala tématem charismatických lídrů a snažila se vymezit jejich osobnostní profil a metody, jichž používají.

V našem příspěvku se budeme zabývat konceptem charismatu učitele a pokusíme se identifikovat, co je pro charismatickou výuku typické.
\end{abstract}

Klíčová slova: vyučování; učení; učitelovo chování; charisma; charismatická výuka.

\section{Introduction}

The HE teacher's personality is a deciding quality factor in the educational process. Experts in various sciences, such as theory of education, educational psychology, philosophy and sociology of instruction have tried to analyse this issue. Different approaches have been used: deduction - when scientists described an ideal teacher, induction - when students evaluated their teachers, or when psychological tests backed the illustration of real personal qualities of teachers. Sometimes, a combination of both approaches seemed appropriate (Bryson, Hand, 2007).

We had reviewed literatures and conducted surveys about the teaching behaviours good teachers in engineering programmes had in common (Dobrovská, 2016, 2017a, 2017b). In our research as well as in a research conducted by J. Davies (2006), students reported various qualities - these can be divided into 3 categories: A good teacher should be an expert in his specialization, he/she should have good didactic, pedagogical and presentation skills and he should have certain human qualities (e.g. humour, disponibility, enthusiasm).

Other authors offered lists of personality attributes - principles of effective teaching in higher education. Ramsden (2003) suggested 6 key principles of a good teacher: interest and explanation, respect for students and student learning, appropriate assessment and feedback, clear goals and intellectual challenge, independence, control (by 
students over their own learning) and engagement. A good teacher should be able to reflect stimula from his/her students.

Unfortunately, too many classroom presentations seem to be based on a similar even-handed approach that robs fascinating subject matter of its intellectual richness and converts it to a bland assemblage of lukewarm facts to be digested for yet another examination (Milojkovic, 1980).

Everyday practice proves students like to attend some teachers' classes because of special characteristics of their personality. We expect there are some reasons make these teachers welcome and attract students. In some resources (Davies, 2005, Dobrovská, 2016 and 2017b), these teachers are simply called quality teachers or good teachers while in other cases the term charismatic teachers was used (Milojkovic, Zimbardo, 1980, Lin and Huang, 2014). Teaching charisma is described as a positive behaviour of a teacher in his class, which can deeply appeal students to learn. While the teacher is perceived approachable, well prepared and sensitive to student needs, students might be committed to work harder. Students are more likely to be receptive to learning under his/her supportive social climate in the classroom. The teacher plays important role in developing such environment and has a strong impact on their students (Lin and Huang, 2014).

\section{The Concept of Charisma}

The term charisma was used by St. Paul to describe the gifts of divine grace which manifest themselves in forms such as prophecy and healing. In the late nineteenth century, it was picked up by Rudolf Sohm as part of his historical analysis of the way by which inspired individuals transformed Christianity into the charismatic Catholic Church, bearing the mission of redemption (Eatwell, 2014).

\subsection{Historic Approach}

Since the early twentieth century, the term has been especially associated with the German sociologist, Max Weber, who in many ways anticipated the challenges to liberal democracy which were to emerge from new forms of political movement and dictatorial regime in the post-1918 era. Weber developped insights drawn from his remarkably broad studies into a threefold ideal-typical classification of legitimacy and power. The first type was termed traditional, which he linked with systems such as monarchies. The second he termed bureaucratic, and was associated with institutions such as democracy and political parties. The third Weber termed charismatic (Weber, 1997).

Although his use of the term charisma was not always clear or consistent, Weber's main focus was on the emergence of exceptional, radical leaders in times of crisis. 
Weber believed that such charismatics could attract an affective community of supporters, largely unconcerned with rational economic affairs. However, he thought that it would be difficult to sustain such support as it would require the constant achievement of miracles, and it was unlikely that such personalised rule could be routinised or stabilised - though he did briefly discuss possibilities for continuity, including forms of clan and institutional charisma (Weber, 1997).

Subsequently, the term charisma entered the professional vocabulary of many historians and social scientists, though few have sought to delineate a precise conceptualisation or theory of charisma.

\subsection{Teacher Charisma}

The concept of charisma was not used in the educational area until the break of the 19th and 20th century. Among the first were Milojkovic and Zimbardo who described the concept of teacher charisma on the base of their own life-long experience with charismatic teachers: the charismatic teacher can engender an enthusiasm that may not only ignite a fierce desire for more knowledge and deeper understanding but may also spark a career (Milojkovic, Zimbardo, 2000).

A profile of the charismatic teacher (based on the authors' own classroom experiences as students of electrifying master) is composed of 12 characteristics:

- The charismatic teacher appears to be the absolute master of his/her domain of expertise. Every concept presented appears to have been fully thought through.

- Delight with his/her field is directly apparent and immediately communicated. Selfdisclosures reveal the sophisticated process of thought that lead to his/her present conceptualization of the domain under discussion.

- Insatiable curiosity: charismatic teacher is never satisfied with his/her current level of understanding but continually seeks deeper and fuller explanations. He/she learns from every teaching encounter and is open to new ideas regardless of their source.

- Sincerity: $\mathrm{He} / \mathrm{she}$ has a genuine belief in the importance of the field and is ready to further it.

- Perfect Presentation: The teacher's apparently effortless delivery is smooth and precise. Technical details have been attended to so that all flows like clockwork.

- Overt Assertiveness: He/she proclaims interpretations and analyses with the vigour of one convinced of internal consistency and global completeness. Everything about his/her manner smacks of assertive drive and projects an infectious air of confidence that penetrates the whole classroom.

- High Energy Level: Nothing is approached half-heartedly. Every action is powered with a dynamic force. 
- Dramatic Appreciation: Such teacher has a profound sense of the dramatic combined with an acute appreciation of timing.

- Clear Affect:The teacher does not hesitate to express proper emotional reaction to any facet of his/her endeavour. Facial expression, gross body movements and tone of voice all combine to clearly indicate every affective response.

- Positive Self-Image: The charismatic teacher regards his/her own personality in a positive light and conveys no doubts concerning proper self-worth.

- Sense of Perspective: The power of thought is accentuated by are markably clear perception of the context of the discipline and of the importance of outstanding problems in the field.

- Unity of Purpose: The charismatic teacher reveals to students the path they should take toward a commonly shared goal - the enrichment of both intellect and spirit.

The authors use the term educational seduction typical for charismatic teachers and criticise everyday practice of university teaching. In their view, for the great majority of students, higher education has become sufficiently impersonal to lead most of them to believe that someone cares enough to bother to intellectually seduce them.

Both authors are convinced the students of charismatic teachers marvel at their exceptional ability to rivet their attention not only for a full class period but, more strikingly, over the entire course or school year. The electric quality pervading their classrooms creates a deep impression that is fondly remembered, much admired, and yet poorly replicated in the classrooms of other teachers with equal knowledge and experience (Milojkovic, Zimbardo, 2000).

\subsection{Teacher Personality, Charisma and Related Terms}

Most psychologists involved in researching qualities of successful teachers agree the gift of charismatic teaching is not an exclusive quality only few teachers were born with. Quality teaching is a final result of hard and well organized cognitive activity backed by passionate desire to perform good teaching. Charismatic teaching may be defined as a complex of learnable attitudes, behaviour patterns and skills, not as in-born qualities. Macro-skills of good teaching can be reached by combination of several microcommunication and social skills. Dynamic teaching is a kind of of social interaction with a leading personality of teacher.

Some experts in theory of education focus at the concept of teacher's authority considered a fundamental quality of a good teacher. Neither this term has a clear definition and demarcation. We believe both terms are often related, but not identical. While a charismatic teacher generally posseses informal authority a teacher with informal authority might not always possess teacher charisma. 


\section{Measuring and Training Teaching Charisma}

\subsection{Measuring Teaching Charisma - (ITCCC - Inventory of Teaching Charisma in the College Classroom)}

Taiwanese authors Huang and Lin (2014) researched the topic of teaching charisma. They identified four merits that deeply attract students and are essential for a charismatic teacher.

- First, a charismatic teacher should be knowledgeable, since teaching requires an interweaving of many kinds of specialized and continuously innovated knowledge (also by Dobrovská, 2017b, Minchew, 2001, Neumann, 2018).

- Second, a charismatic teacher should have positive character traits such as friendliness, approachability, patience and enthusiasm (Lin and Huang, 2014) since teachers are expected to be good role models for the students and they should perform what a teacher should have. The teachers' behaviour models, attitudes, appearance and character may affect the feeling students perceive, and may even influence the interaction between teacher and students.

- Third, a charismatic teacher should attach importance to teaching methods. The teachers should possess teaching skills and be able to choose the most suitable teaching method from a variety of teaching tools (also by Labaree, 2000).

- Fourth, a charismatic teacher should have a good sense of humour, since students prefer listening to teachers who incorporate humour into the lecture (also by Davies, 2006).

On the basis of these indicators - knowledge, character traits, teaching methods and humour - an instrument was developped to measure teacher's teaching charisma (Lin and Huang, 2014). Taiwanese authors summarize the ITCCC (Inventory of Teaching Charisma in the College Classroom) was found a valid and reliable tool to measure the phenomenon in the accounting fundamental course in Taiwan.

\subsection{Czech version of the ITCCC}

Both Taiwanese authors noted limitations in their study and suggested the measurement invariance of their scale across different subjects needs to be examined. That is why we conducted a preliminary study translating the English version of the ITCCC into Czech and submitting it in an engineering pedagogy course (Dobrovská, 2018). Comparing the mean, SD and Cronbach a coefficient for each of four factors results showed no significant differences from the original Taiwanese scale. On the other hand some 
more research should be carried out to confirm whether the scale covers all qualities of a charismatic teacher as few items relate to the electric qualities of a charismatic teacher as formulated by Milojkovic and Zimbardo.

When we analyse content of all 23 items of the ITCCC the first subscale is an equivalent of what is called expertise by J. Davies (2006) - based on cognitive qualities of teachers. The second subscale contains items corresponding to personal qualities. The third one (with only 4 items of 23) is dedicated to didactic skills and cannot cover all spectrum of teaching methodologies. Last subscale (7items of 23) relates to humour and some of these items are the only ones which relate to emotional impact in teaching. If we agree with the concept of charismatic teaching bringing an extra value of specific emotional effects on students some items need modification.

\subsection{Suggestions How to Train Charismatic Teaching}

Zimbardo characterised charismatic teaching as energizing. His conviction was that teaching charisma can be trained. It takes work, but inspired, evolving instruction makes all the difference to students (Zimbardo, 2003). Beyond just imparting knowledge, teachers have to add sparkle so students absorb and retain information.

Some universities organize workshops - when developping teaching style, experience with communication skills training can be used with some modifications. During specialised courses or workshops, participants (future teachers) engage in a number of exercises designed to enhance classroom interaction skills.

Minchew (2001) reports one exercise involves students preparing a 5-10 minute talk on a topic they consider to be one of the most interesting in their discipline. They then deliver this mini-lecture playing the role of the most boring instructor they have ever had. After a group discussion of the finer features of the much practiced art of being boring, participants are urged to think about the overt behaviours of charismatic teachers. They re-give their talk displaying these behaviours to the group and to a videotape camera. These tapes form the basis for further group discussion about the distinctions between the assertive versus the aggressive teacher, the dynamic versus the overbearing teacher, and the effective educator versus the merely flamboyant showperson.

It should be clear that this and other exercises practiced in the workshops are shortterm experiences that serve to highlight only some of the features of outstanding teaching. In addition, one must adopt a long-term approach to effective teaching during which various techniques are sought, tried and discarded as appropriate. 


\section{Conclusions}

Although there is no general consent in defining teaching charisma we agree with Milojkovic and Zimbardo describing teaching charisma as positive behaviours of teachers, which can emotionally appeal students to learn. An emphasis throughout is to constantly strive for superb teaching that excites and inspires. Although not every teacher can become charismatic, for each of the abstract principles of charismatic teaching, a set of operational tactics and strategies can be realized by training. Charismatic teachers are not only masters of their subject areas but that they also have a keen understanding of group dynamics, develop excellent social skills, and learn how to display a range of motivating styles.

\section{References}

Bryson, C. \& Hand, L. (2007). The Role of Engagement in Inspiring Teaching and Learning. Innovations in Education and Teaching and Learning, 44(4), 349-362, DOI: 10.1080/14703290701602748.

Davies, J., W. et al. (2006). What Makes a Good Engineering Lecturer? \\ put Their Thoughts in Writing. European Journal in Engineering Education, 31(5), 543-553. DOI: 10.1080/03043790600797285.

Dobrovská, D. (2016). Motivation to Soft Skills Education and Training in Engineering Education. In Miština, J. \& Hrmo, R. Key Competencies and the Labour Market. Scientific Monograph. Warsaw: Warsaw Management University Publishing House.

Dobrovská, D. (2017a). Academic Readiness of Mature-Age Students. In Advances in Intelligent Systems and Computing. London: Springer, pp. 525-531.

Dobrovská, D. (2017b). Quality Engineering Teaching for Quality Engineering Learning. In Edulearn Proceedings, pp. 6785-6789.

Dobrovská, D. (2018). Measuring Teacher Charisma. Media4u, 2.

Eatwell, R. (2014). The Concept and Theory of Charisma (PDF Download Available). From: https:// www.researchgate.net/publication/233349421_The_Concept_n d_Theory_of_Charisma [accessed Mar 21 2018].

Koehler, M. J. \& Mishra, P. (2009). What is Technological Pedagogical Content Knowledge? Contemporary Issues in Technology and Teacher Education, 9(1), 60-70.

Labaree, D. F. (2000). On the nature of teaching and teacher education: Difficult practices that look easy. Journal of Teacher Education, 51(3), 228-233.

Lin, S. \& Huang, Y. (2014). Examining Teaching Charisma and its Relation to Student Engagement. Cross-Cultural Communication, 10(6), 1-8.

Milojkovic, J., D. \& Zimbardo, P., C. (1980). Charismatic teaching: Its nature and development. In University of Maryland University College., École polytechnique fédérale de Lausanne., \& International Conference on Improving University Teaching. Improving University Teaching: Sixth International Conference: July 9-12, 1980, Lausanne Switzerland. University of Maryland University College.

Minchew, S., S. (2001). Teaching English with Humour and Fun. American Secondary Education. 30(1), pp. 58-68.

Neumann, D., L. (2018). Statistics? You must be Joking: The Application and Evaluation of Humour when Teaching Statistics. Retrieved 2018, February 10 from http://www.amstat.org/publications/ jse/v17n2/neumann.pdf 
Ramsden, P. (2003). Learning to Teach in Higher Education. 2nd Edition. London: Routledge Falmer. Weber, M. (1997). Autorita, etika a společnost. Praha: Mladá fronta, 1997.

Zimbardo, P. (2003). Charismatic Teaching = Energized Students. Monitor, 34(10), 28-36.

\section{Contact:}

Doc. PhDr. Dana Dobrovská, CSc., Masaryk Institute of Advanced Studies,

Czech Technical University in Prague, Kolejní 2a,

16000 Prague 6, Czech Republic

E-mail: dana.dobrovska@muvs.cvut.cz

Doc. PhDr. Dana Dobrovská, CSc., psychologist, engaged in technical teacher education and its psychological aspects, delivered lectures in HE institutions in Austria, Great Britain and Estonia. 